\title{
Fibroma ameloblástico versus quiste folicular hiperplásico
}

\author{
Ameloblastic fibroma versus hyperplastic follicular cyst
}

\author{
J. Azúa-Romeo', E. Saura Fillat², T. Usón Bouthelier², M. Tovar Lázaro33, J. Azúa Blanco ${ }^{4}$
}

Resumen: El fibroma ameloblástico (FA) es un tumor odontogénico mixto, compuesto por tejido mesenquimal y epitelio odontogénico, representando el $2 \%$ de los tumores odontogénicos, mientras que el quiste dentígero o folicular (QF), el segundo quiste odontogénico en frecuencia, está compuesto exclusivamente por tejido conjuntivo laxo (mesénquima), si bien, el saco fibroso puede contener restos de epitelio odontogénico incluidos, dando lugar a una imagen histológica muy similar.

La importancia de esta diferenciación radica en el tratamiento, que es ligeramente más agresivo en el FA y en el comportamiento biológico, ya que el FA puede derivar en un sarcoma ameloblástico, y el QF puede evolucionar hacia ameloblastoma y más raramente carcinoma mucoepidermoide.

Palabras clave: Fibroma ameloblástico; Tumor odontogénico; Quiste folicular.

\section{Introducción}

Presentamos el caso de un varón de 16 años al que se le practica exodoncia de cordal incluido mandibular derecho. El posterior estudio histológico informa de fibroma ameloblástico, tumor odontogénico mixto benigno.

En el presente trabajo cuestionamos la frecuencia de dicha entidad ( $2 \%$ de tumores odontogénicos) prestando especial atención

\footnotetext{
1 Especialista en Anatomía Patológica. Profesor Asociado de Histología. Universidad de Zaragoza, España.

2 Médico Adjunto. Servicio de Cirugía Oral y Maxilofacial. Hospital Universitario Miguel Servet. Zaragoza, España.

3 Médico Adjunto. Servicio de Urgencias. Mutua de Accidentes de Zaragoza.

4 Especialista en Anatomía Patológica. Profesor Titular de Histología. Universidad de Zaragoza, España.
}

\section{Correspondencia:}

Dr. Javier Azúa-Romeo

$S^{\circ}$ Anatomía Patológica (Banco de Tumores)

Hospital Universitario Miguel Servet

$\mathrm{P}^{\circ}$ Isabel la Católica 1 y 3

50009 Zaragoza, España

Email: javierazua@hotmail.com
Abstract: Ameloblastic fibroma (AF) is a mixed odontogenic tumor composed of mesenchymal tissue and odontogenic epithelium, accounting for $2 \%$ of all odontogenic tumors, while dentigerous or follicular cyst (FQ), second odontogenic cyst in frequency, is formed exclusivelly by soft conective tissue (mesenchyme). Nevertheless, hiperplastic fibrous sac may contain rests of odontogenic epithelium, showing a similar histologic pattern.

The importance of an adequate differentiation lies in the treatment, which is slightly aggresive for $A F$, and regarding the biological behaviour of both lesions, since AF might become in an ameloblastic sarcoma, while over an FQ could develope an ameloblastoma or even a mucoepidermoid carcinoma.

Key words:

Key words: Ameloblastic fibroma; Odontogenic tumor; Follicular cyst.

\section{Introduction}

We present the case of a 16 year old male who had an embedded wisdom tooth on the right side extracted. The subsequent histological study reported ameloblastic fibroma, benign mixed odontogenic tumor.

In this study we question the frequency of this entity (2\% of odontogenic tumors) and give special attention to the differential diagnosis with the hyperplastic follicular cyst which shows similar histological characteristics.

This interest is based essentially on differering biological behavior and the therapeutic protocol that should be applied.

\section{Clinical Case}

A 16-year-old male patient, with no previous medical or odontological history of interest enquired about extracting an embedded wisdom tooth on the right side of the mandible for orthodontic reasons. The tooth had not shown any clinical inflammation. The orthopantomography (Fig. 1) showed a radiolucent image with radiopaque borders surrounding 
al diagnóstico diferencial con el quiste folicular hiperplásico, que muestra características histológicas similares.

El interés fundamental radica en el diferente comportamiento biológico y el protocolo terapéutico a aplicar.

\section{Caso clínico}

Se trata de un paciente varón de 16 años de edad, sin antecedentes médicos ni odontológicos de interés, que consulta para exodoncia de cordal incluido mandibular derecho por motivos ortodóncicos. La pieza no había dado clínica inflamatoria, presentando únicamente en la ortopantomografía (Fig.1) una imagen radiolúcida con bordes radioopacos alrededor de un molar no erupcionado. La lesión contenía focos aislados de material calcificado. En conjunto la imagen sugería la presencia de un quiste odontogénico, por lo que el diagnóstico diferencial macroscópico incluye el quiste dentígero o folicular (QF), quiste odontogénico calcificante, queratoquiste y como opción menos probable algún tipo de odontoma.

Se procedió a exodoncia quirúrgica del cordal bajo anestesia local, previa ostectomía, realizando también exéresis de la lesión de aspecto quístico pericoronario, que se remitió para estudio histopatológico, no considerando necesario realizar examen intraoperatorio.

La muestra tisular se procesa de manera rutinaria realizando tinción con hematoxilina-eosina. El examen con microscopía óptica revela un tejido de apariencia

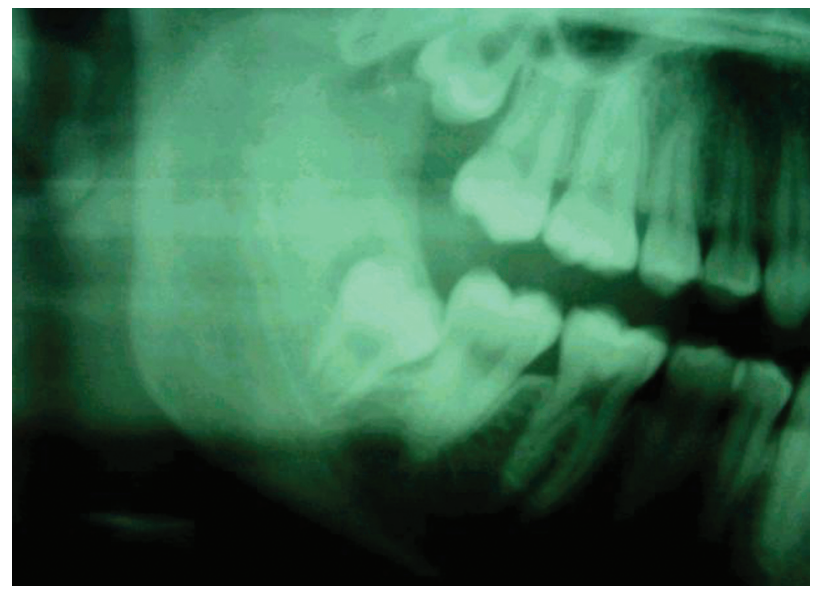

Figura 1. Ortopantomografía que muestra lesión radiolúcida pericoronal en molar no erupcionado.

Figure 1. Orthopantomography showing pericoronal radiolucent lesion in unerupted molar.

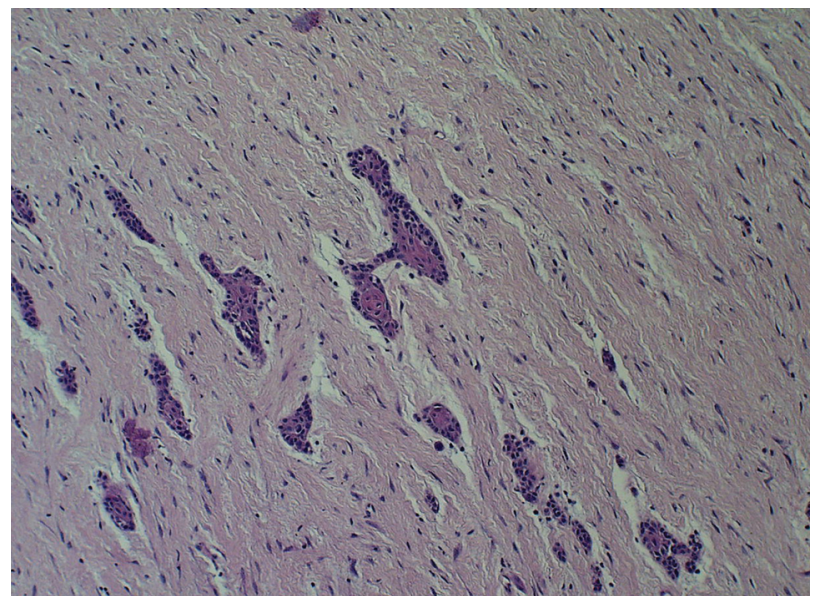

Figura 2. Imagen histológica en la que se aprecia un tejido mixoide laxo, con islotes de epitelio odontogénico típico. (Hematoxilina-eosina, magnificación original $\times 10$ ).

Figure 2. Histological image in which a myxoid, loose tissue, with typical odontogenic epithelial islands can be appreciated. (Hematoxylineosin, original magnification $\times 10$ ). mixoide, junto con nidos o hebras de epitelio odontogénico. Un estudio con mayor aumento muestra un tejido conectivo laxo entre el que encontramos fibroblastos fusiformes y macrófagos, como células propias de este tejido, y los referidos islotes de epitelio odontogénico, formados típicamente por dos hileras de células epiteliales de morfología uniforme, con núcleos redondeados u ovales y escaso citoplasma eosinófilo, sin evidencia de malignidad o transformación atípica (Fig. 2).

El curso post-quirúrgico fue completamente satisfactorio, sin evidencia de lesión residual 6 meses después de la intervención.

\section{Discusión}

La primera referencia que se tiene del fibroma ameloblástico se debe a Kruse en 1891,1 desde entonces se han publicado dife- an unerupted molar. The lesion contained isolated pockets of calcified material. The overall image suggested the presence of an odontogenic cyst, and for this reason the macroscopic differential diagnosis included the dentigerous or follicular cyst (FC), calcifying odontogenic cyst, keratocyst and, as the least likely option, some type of odontoma.

The wisdom tooth was extracted, following an osteotomy, with local anesthetic. Exeresis of the pericoronal cystic-looking lesion was also carried out and it was sent for histopathologic study, as carrying out an intraoperative examination was not considered necessary. The tissue sample was routinely processed by means of staining with hematoxylin-eosin. The optical microscopical examination showed tissue with a myxoid appearance, together with clumps or threads of odontogenic epithelium. A study with more magnification showed loose connective tissue which revealed fusiform fibroblasts and macrophages, a well as cells typical of the tissue, and the previously reported islands of odontogenical epithelium, typically formed by two strands of epithelial cells with uniform morphology, with rounded or oval nuclei and limited eosinophile cytoplasm, with no evidence of malignancy or atypical transformation (Fig. 2). The post-surgical period was completely satisfactory, with no residual evidence of the lesion six months after the intervention.

\section{Discussion}

The first reference to ameloblastic fibroma was by Kruse in 1891. ' Following this many cases and revisions have been published, and a frequency of between 1 and 3\% of odontogenic tumors was established according to the series. Our 
rentes casos y revisiones, estableciendo la frecuencia entre el 1 y el $3 \%$ de los tumores odontogénicos según las series. En nuestra experiencia encontramos una frecuencia muy inferior, no superando el 0,5\%, ya que de los 500 pacientes estudiados desde 1995 tan sólo hemos encontrado un caso, el actual. Las características clínicas de este tumor son muy típicas, destacando la edad media de 12 años, con un límite superior en 40 años, sin existir diferencia de aparición por sexos y siendo la localización más frecuente el área molar mandibular. ${ }^{2}$

Radiográficamente, estas lesiones suelen aparecer bien definidas, transparentes, con un halo más esclerosado radioopaco. Pueden ser uniloculares o multiloculares y se suelen asociar con la corona de dientes impactados. ${ }^{3}$ Si dentro de la lesión se observa un área más opaca, orienta el diagnóstico hacia un fibroodontoma ameloblástico, indicando la presencia de un pequeño odontoma, ya que el FA es completamente lúcido radiográficamente. ${ }^{1}$

El diagnóstico definitivo se alcanza con el estudio microscópico, encontrando un tejido conectivo laxo, de aspecto mixoide, con células fusiformes (fibroblastos) que presenta entremezclado nidos o hebras de epitelio odontogénico constituido por células cuboideas, de núcleo redondeado sin atipias, de 2-3 células de espesor. En algún caso las células epiteliales odontogénicas continúan su diferenciación dando lugar a la producción de dentina y esmalte, típico del fibro-odontoma, y configurando una patrón de odontoma compuesto o complejo, sin implicar diferencias en el tratamiento o comportamiento biológico futuro.

Cuando la lesión reúne todas las características de edad, localización e imagen radiográfica, el diagnóstico inicial es bastante sencillo; el problema surge, cuando falla alguna de esas características. ${ }^{4}$ En nuestro caso el paciente se encontraba dentro del rango de edad y la localización era típica, sin embargo la total ausencia de clínica y la radiología inespecífica no orientaban hacia este tipo de tumor, sino hacia un quiste odontogénico. Por lo tanto, en el diagnóstico diferencial debemos incluir muchas entidades, siendo las más frecuentemente citadas el ameloblastoma, mixoma odontogénico, quiste dentígero, queratoquiste odontogénico, granuloma central de células gigantes e histiocitosis.

En este sentido sería fácil pensar que el resultado final está en las manos del patólogo, el cual, con una mínima experiencia en patología oral debería ser capaz de diferenciar todas las entidades referidas previamente y alcanzar el diagnóstico definitivo de fibroma ameloblástico. Nosotros queremos incidir en la dificultad del diagnóstico histológico y en la necesidad de aportar todos los datos clínicos necesarios al patólogo. En primer lugar ya hemos comentado la baja frecuencia del FA, alrededor del 2\% de los tumores odontogénicos, mientras que, por el contrario, el QF representa el segundo tipo más frecuente de quistes de ésta localización, por lo que con estos datos parece razonable pensar antes en un QF. La edad del paciente no ayuda mucho en este caso, ya que ambas lesiones son más frecuentes en la segunda década, si bien la localización es muy típica para el FA, siendo la radiología también similar, aunque en el caso de QF es más habitual que sean lesiones uniloculares, radiotransparentes y sin refuerzo esclerosante periféri$\mathrm{co}$, incluyendo el diente impactado. experience discovered a much lower frequency which was not above $0.5 \%$ as, in the 500 patients studied from 1995, we have only come one case which is this one. The clinical characteristics of this tumor are very typical, significantly the average age is 12 , with a superior age limit of 40 . It appears with equal frequency in males and females, and it is most likely to found in the molar area of the mandible. ${ }^{2}$

These lesions are radiographically well defined, transparent, but with a halo which is more sclerotic and radiopaque. They can be unilocular or multilocular and they tend to be associated with the crown of the impacted tooth. ${ }^{3}$ If a more opaque area is observed within the lesion this guides the diagnosis towards ameloblastic fibro-odontoma, indicating the presence of a small odontoma, as the AF is completely lucent radiographically. ${ }^{1}$

The definitive diagnosis is reached with a microscopical study, as loose connective tissue is found, of myxoid appearance, with fusiform cells (fibroblasts) and clumps or strands of odontogenic epithelial cells made up of cuboid cells, with rounded nuclei having no atypia, and a 2-3 cell thickness. In some cases the odontogenic epithelial cells continued their differentiation giving rise to the production of dentine and enamel, typical of fibro-odontoma, forming a pattern of compound or complex odontoma, which does not imply any difference in future treatment or biological behavior.

When the lesion has all the characteristics regarding age, localization and radiographic image, the initial diagnosis is quite simple. The problem arises when there is a failure in one of the characteristics. ${ }^{4}$ In this case our patient was within the age range and the localization was typical. However, the total absence of symptoms and the unspecific radiography did not guide us towards this type of tumor, but rather towards an odontogenic cyst. Therefore, the differential diagnosis should contain many entities, the most frequently included being ameloblastoma, odontogenic myxoma, dentigerous cyst, odontogenic keratocyst, central giant cell granuloma and histocytosis.

In this sense it would be easy to think that the final result lies in the hands of the pathologist who, with a minimum experience in oral pathology would be able to differentiate all the entities previously mentioned, in order to reach a definitive diagnosis of ameloblastic fibroma. We would like to stress the difficulty of histologic diagnosis and the need to give the pathologist all the relevant clinical data. Firstly, as we have already commented, there is the low incidence rate of $A F$, around $2 \%$ of odontogenic tumors, while on the other hand, the FC represents the second most frequent type of cyst in this localization. Therefore with this data it would be reasonable to first think of FC. The age of the patient is not of much help in this case, as both lesions are more frequent in the second decade of life, although the localization is very typical for AF, the radiography is also similar. In the case+ of FC lesions are more likely to be unilocular, radiotransparent and without peripheral sclerotic borders, including the impacted tooth. 
La pieza remitida al patólogo debe estudiarse en su totalidad, no pudiendo «fiarse» de la aparente benignidad de la misma, ayudando en gran medida el hacer constar en la petición la impresión diagnóstica clínica. Concretamente en nuestro caso, al realizar el examen histológico se evidenció en uno de los fragmentos un tejido mixoide con fibroblastos sin otra celularidad acompañante; sin embargo, el estudio detallado de todos los fragmentos tisulares reveló los islotes de tejido epitelial dispersos en el estroma mesenquimal, reorientando el diagnóstico.

Desde el conocimiento de la etiopatogenia de estas dos entidades es más fácil comprender el comportamiento biológico y su evolución. El quiste folicular, por definición, está constituido exclusivamente por tejido conectivo laxo mixoide, pero la cápsula que lo recubre presenta un epitelio odontogénico típico, escamoso estratificado, que incluye algunas células mucosecretoras características. En el desarrollo del QF en el que se acumula fluido entre el esmalte y la corona dental, el epitelio odontogénico forma una de las paredes del quiste y desde este epitelio se pueden desprender restos celulares que quedaran atrapados en el estroma mixoide neoformado. ${ }^{1}$ Por lo tanto, se trata de un solo tejido constituyente.

En el caso del FA, el componente mayoritario es el tejido mesenquimal primitivo, compuesto por haces de tejido conectivo laxo y células indiferenciadas, con capacidad para convertirse en cualquier línea celular, que en la evolución de este tumor se transforman en células epiteliales odontogénicas, lo que lo convierte en un tumor odontogénico mixto benigno.

Para el correcto diagnóstico una de las claves es la mayor celularidad mesenquimal en el $\mathrm{FA}^{5-7}$ junto con haces de epitelio odontogénico distribuidos de manera uniforme por toda la lesión, a diferencia de lo que sucede en el quiste folicular en el que estos haces se encuentran circunscritos a la proximidad de la cápsula.

Consideramos que muchos de los casos etiquetados como fibroma ameloblástico corresponden en realidad a QF hiperplásicos, con inclusiones epiteliales.

En cuanto al tratamiento en el FA se acepta que la actitud más indicada es conservadora, extirpando la lesión y el diente incluido si lo hay, con curetaje del hueso circundante a la lesión, en el caso del QF no parece necesario el curetaje óseo. En el caso que presentamos se evitó el curetaje ya que no existía sospecha previa que lo indicara, de cualquier modo una vez obtenido el diagnóstico anatomopatológico tampoco se consideró necesario realizar un segundo acto quirúrgico, proponiendo controles periódicos al paciente, que permanece asintomático

La evolución y pronóstico son muy favorables en ambos casos, si bien es conveniente conocer que el FA puede derivar en un sarcoma ameloblástico, y en el caso del QF se han descrito malignizaciones en forma de ameloblastoma y más raramente carcinoma mucoepidermoide. ${ }^{5}$

\section{Conclusiones}

En conclusión, todas las lesiones de la cavidad oral, incluyendo las periodontales y glándulas salivares, ${ }^{8}$ deben ser estudiadas
The sample sent to the pathologist should be completely studied. One cannot «trust» an apparent benign appearance, and it is of great help including in the petition any impression as to the clinical diagnosis. In our case in particular, on carrying out the histological examination one of the fragments showed myxoid tissue with fibroblasts with no other accompanying cellularity. However, detailed analysis of tissue fragments revealed islands of epithelial tissue dispersed within the mesenchymal stroma, redirecting the diagnosis.

With etiopathogenic knowledge of these two entities it is easier to understand the biological behavior and evolution. The follicular cyst by definition consists exclusively of myxoid, loose connective tissue but the capsule which covers it presents typical odontogenic epithelium, which is stratified and squamous, and it includes some characteristic mucosecretory cells. In the development of the FC in which fluid is accumulated between the enamel and the dental crown, the odontogenic epithelium forms one of the walls of the cyst and, from this epithelium, remains can become detached and become trapped in the newly formed myxoid stroma. It therefore consists of just one constituting tissue.

With $A F$, the major component is the primitive mesenchymal tissue, composed of clusters of connective tissue and similar-looking cells, with a capacity of converting themselves into any type of cellular line, and which, during the evolution of the tumor, will become odontogenic epithelial cells turning it into a benign mixed odontogenic tumor.

For the correct diagnosis one of the key issues is the greater mesenchymal cellularity of the $A F^{5-7}$ as well as the clusters of odontogenic epithelium distributed in a uniform manner through out the lesion, which is different to the follicular cyst in which these clusters are confined to the edge of the capsule.

We consider that many of the cases labeled as ameloblastic fibroma correspond in reality to hyperplastic FCs with epithelial inclusions.

With regard to AF treatment we accept that conservative treatment is the most suitable - removing the lesion and the impacted tooth should there be one, with curettage of the bone around the lesion. Bone curettage for FC appears not to be necessary. In the case we present curettage was avoided, as there was no previous indication to warrant this. In any event, once the anatomopathologic diagnosis was obtained, a second surgical procedure was not considered necessary. The patient is under periodic control and remains asymptomatic.

In both cases evolution and prognosis are favorable, although it is convenient to know that AF can turn into an ameloblastic sarcoma, and regarding FC malignancies in the form of ameloblasts have been described and, more rarely, mucoepidermoid carcinoma. ${ }^{5}$

In conclusion, all lesions of the oral cavity, including periodontal and salivary gland lesions, should be studied in detail, 
con detalle, sin confiar en la aparente benignidad de las mismas, integrando los datos clínicos, radiológicos e histológicos para adecuar el protocolo terapéutico y clínico a la realidad biológica de la lesión.

\section{Bibliografía}

1. Kruse A. Uber die Entwicklung Cystichen Gesschwulse in Unterkiefer. Arch F Pathol Anat 1891;124-37.

2. Regezi J, Sciubba J. Oral Pathology. Philadelphia, PA: WB Saunders Company Ed. 1999.

3. Martín-Granizo R, Ortega L, González Corchón A, Berguer Sández A. Fibroma ameloblástico mandibular. Presentación de dos casos. Medicina Oral 2003;8:1503.

4. McGuinness NJ, Faughnan T, Bennani F, Connolly CE. Ameloblastic fibroma of the anterior maxilla presenting as a complication of tooth eruption: a case report. J Orthod 2001;28:115-8.

5. Takeda Y. Ameloblastic fibroma and related lesions: current pathologic concept. Oral Oncol 1999;35:535-40.

6. Chang H, Shimizu M, Precious D. Ameloblastic fibro-odontoma: a case report. J Can Dent Assoc 2002;68:243-6.

7. Shimoyama T, Horie N, Ide F. Clarification of diagnostic criteria for ameloblastic fibroma. J Oral Maxillofac Surg 1999;57:219.

8. Azua-Romeo J, Uson T, Martinez-Tello A, Álvarez-Alegret R, Moral I. Epithelialmyoepithelial carcinoma arising from clear cell myoepithelioma of the parotid. Pathology 2002;34:475-7. and one should not rely on their apparent benignity. Clinical, radiological and histological data should be integrated in order to adapt therapeutic and clinical protocol to the biological reality of the lesion. 